\title{
Pengembangan Profesionalisme Guru Melalui Kegiatan Lesson Study di Pondok Pesantren Nurul Haramain Putra NW Narmada: Manfaat dan Tantangannya
}

\author{
Muhammad Amin*, Mahyuni**, Lalu Jaswadi Putera*** \\ Universitas Mataram \\ *muhammad_amin@unram.ac.id \\ ***lalujaswadi1981@gmail.com
}

\begin{abstract}
Due to the dynamic and ever-changing contexts of their work, teachers need to continuously develop their professionalism. One professional development procedure close enough to teachers' work place, the classroom, is Lesson Study (LS). This paper illustrates the potentials benefits of implementing LS in one Islamic school in Lombok and the challenges of implementing this procedure in this particular school. Data were collected through distribution of questionnaire to 31 teachers of this school. Results of data analysis indicate that all teachers are positive about the advantages of applying $L S$ in their classrooms. However, they are also aware of the potential challenges of implementing this professional development procedure in the school, which needs careful consideration. Following a list of all these challenges is recommendation of how to deal with them.
\end{abstract}

Keywords: Lesson Study, Islamic Boarding School, Teacher Professionalism, Teacher Professional Development

\begin{abstract}
Abstrak : Disebabkan konteks pekerjaan mereka yang dinamis dan selalu berubah, para guru khususnya di pondok pesantren perlu terus mengembangkan profesionalisme mereka agar tidak ketinggalan oleh pesatnya perkembangan ilmu pengetahuan dan terus dapat memberi kontribusi yang berarti bagi kualitas pendidikan. Salah satu kegiatan pengembangan profesionalisme guru yang cukup dekat dengan tempat kerja mereka yakni ruang kelas adalah Lesson Study (LS). Tulisan ini bertujuan untuk memetakan gambaran potensi manfaat penerapan LS di sekolah Islam di Lombok dan untuk mengetahui tantangan apa saja yang dihadapi oleh para guru di pondok pesantren. Data dikumpulkan melalui pendistribusian kuesioner dan wawancara kepada 31 guru di pondok pesantren ini. Hasil analisis menunjukkan bahwa para guru memandang positif kegiatan LS ini di kelas mereka. Namun, mereka juga menyadari adanya tantangan atau hambatan dalam pelaksanaan kegiatan ini yang perlu dipertimbangkan. Tantangan atau hambatan dalam penerapan kegiatan LS ini diharapkan dapat menjadi rekomendasi untuk mengatasinya.
\end{abstract}

Kata Kunci: Lesson Study, Pondok Pesantren, Profesionalisme Guru, Pengembangan Profesionalisme Guru 


\section{PENDAHULUAN}

Peran guru dalam peningkatan mutu pendidikan tidak dipertanyakan lagi. Hal ini disebabkan oleh besarnya pengaruh guru terhadap pembelajaran siswa. Dalam sebuah penelitian yang dilakukan Darling-Hammond ${ }^{1}$ ditemukan bahwa dibandingkan dengan faktor-faktor lain yang berpengaruh terhadap pembelajaran siswa, termasuk di antaranya faktor ekonomi, ras dan pendidikan orang tua, guru memiliki pengaruh terbesar. Secara lebih spesifik $\mathrm{Hattie}^{2}$ dalam sebuah penelitiannya menemukan bahwa secara persentase capaian pembelajaran siswa 30\% ditentukan oleh kualitas guru. Dengan demikian kalau kita hendak meningkatkan kualitas pembelajaan di kelas ataupun pendidikan secara umum maka peningkatan kualitas guru merupakan suatu keniscayaan. Meskipun peran guru sangat penting sering kali pengembangan profesionalisme guru tidak mendapat perhatian yang memadai. Sering kali guru terjebak pada pelaksanaan tugas rutin sehari-hari sehingga tidak ada waktu yang diluangkan untuk melakukan pengembangan profesionalisme mereka. Hal ini sering berakibat pada proses pelaksanaan tugas mengajar yang tidak berkembang secara kualitas baik dalam konten maupun proses (metodologis).

Apabila hal ini terus terjadi, tentu dapat berakibat kurang baik baik bagi guru itu sendiri maupun terhadap siswa yang diajarnya. Bagi guru tersebut keadaan ini akan menimbulkan kebosanan yang mungkin berakibat keinginan keluar dari profesi sebagai guru (teacher burnout) dan kalaupun tetap menjalani profesi ini, guru tersebut tidak berkembang secara profesional dan personal. Sedang bagi siswa dampak yang mungkin timbul adalah tidak adanya potensi pembelajaran yang optimal. Idealnya guru harus selalu melakukan proses pengembangan diri secara terus menerus (continuing professional development) sehingga bisa terus mengikuti perkembangan dan dampak negatif seperti teacher burnout dan kurang optimalnya pembelajaran siswa dapat dihindari.

Minimnya aktivitas pengembangan profesionalisme guru sering diakibatkan oleh terbatasnya pemahaman guru akan proses pengembangan profesionalisme dimaksud. Seringkali mereka menganggap bahwa pengembangan profesionalisme

1 Linda Darling-Hammond, dkk., "Educating Teachers for California's Future", Teacher Education Quarterly, Vol 28 (1): 9-55, 2001.

2 John Hattie, dkk., "An Integrated Professional Development Model for Effective Teaching”, Teaching and Teacher Education 26: 1687-1694, 2010. 
harus selalu datang dari luar diri mereka, seperti mendatangkan ahli yang akan memberikan ceramah atau pelatihan di sekolah mereka, atau guru harus meninggalkan sekolah untuk menghadiri seminar, konferensi, atau workshop, dan lain-lain. Hal ini memang tidak salah karena kegiatan yang disebutkan tersebut adalah beberapa bentuk pengembangan profesionalisme guru. Akan tetapi bahwa pengembangan profesionalisme dapat dilakukan dengan cara yang lain perlu juga disosialisasikan kepada mereka. Salah satu dari program peningkatan profesionalisme guru yang bisa dilakukan adalah mengembangkan sikap reflektif dan kolaboratif, reflektif terhadap proses menjalankan tugas dan fungsi sebagai guru dan kolaboratif dengan rekan guru dan stake holder yang lain dalam rangka mengembangkan profesionalisme mereka.

Salah satu bentuk kegiatan pengembangan profesionalisme guru yang melibatkan kedua sikap tersebut terutama dalam meningkatkan mutu pembelajaran di kelas adalah kegiatan Lesson Study.

\section{KAJIAN PUSTAKA}

\section{Pentingnya Pengembangan Profesionalisme Guru}

Pengembangan profesionalisme dapat didefinisikan sebagai sebuah proses yang dinamis yang dilakukan seorang guru dalam mengembangkan diri baik secara personal dan profesional dalam menjalankan tugas sebagai seorang guru. ${ }^{3}$ Sebagai sebuah proses maka usaha ini harus dilakukan dengan menerapkan konsep belajar sepanjang hayat (life-long learning) dan terus menerus (continuing professional development). Proses ini tidak selalu sama antara satu guru dengan guru yang lain (idiosyncratic) baik dari segi waktu maupun proses yang ditempuh. Ada banyak faktor yang mempengaruhi perkembangan profesionalisme guru, baik faktor personal maupun environmental, maupun faktor sebelum menjadi guru (prior to teacher induction) dan setelah menjadi guru (after induction). ${ }^{4}$

\footnotetext{
${ }^{3}$ Muhammad Amin, "What Makes Teachers of EFL Professional or Unprofessional", Universitas Negeri Malang, Disertasi tidak dipublikasikan, 2013.

${ }^{4}$ Muhammad Amin \& dan Ali Saukah, "What Makes Teacher of EFL Professional or Unprofessional, Jurnal Excellence in Higher Education, Vol. 6, pp 12-20, 2015.
} 
Besarnya pengaruh guru terhadap pembelajaran siswa sudah banyak diteliti. $^{5,6,7,8}$ Dari semua penelitian yang dilakukan ditemukan adanya hubungan yang positif antara kualitas guru yang mengajar dengan capaian pembelajaran. Dengan kata lain, kualitas guru berbanding lurus dengan tingkat capaian pembelajaran siswa. Dengan demikian apabila kita hendak meningkatkan capaian pembelajaran siswa, maka mau tidak mau harus dilakukan peningkatan kualitas guru yang mengajar mereka.

\section{Bentuk-bentuk Pengembangan Profesionalisme Guru}

Dari sisi kapan pengembangan profesionalisme dilakukan maka terdapat dua jenis pengembangan profesionalisme: pengembangan yang dialkukan sebelum menjadi guru, atau yang disebut pre-service teacher education (PSTE), dan pengembangan setelah menjadi guru yang disebut in-service teacher education (ISTE). PSTE meliputi pendidikan atau pelatihan yang dilakukan seseorang sebelum diangkat menjadi guru. Dalam Undang-Undang Guru dan Dosen no 14 tahun 2005 misalnya, untuk menjadi seorang guru pada jenjang pendidikan dasar dan menengah seseorang harus memiliki kualifikasi pendidikan setara strata 1 (S1) atau diploma 4 (D4). Sedangkan kegiatan ISTE mencakup semua kegiatan pengembangan diri baik berupa training, mengikuti seminar dan konferensi, penataran, pelatihan dan sebagainya. Dalam hal pemberdayaan dan pengembangan guru, dalam undang-undang tersebut pada Bab III ayat 2 tentang Prinsip Profesionalitas dijelaskan bahwa pengembangan diri guru harus dilakukan secara "demokratis, berkeadilan, tidak diskriminatif, dan berkelanjutan". Hal ini menuntut guru sebagai individu dan salah satu pemegang andil utama pendidikan berkewajiban untuk

\footnotetext{
${ }^{5}$ Linda Darling-Hammond, Teacher Quality and Student Achievement: A review of state policy evidence, Education Policy Analysis Arcbives, 8 (1), 2000.

${ }^{6}$ Linda Darling-Hammond, et al, "Educating Teachers for California's Future", Teacher Education Quarterly, Vol 28 (1):9-55. 2001.

7 Leonidas Kyriakides. et al., Teacher Behaviour and Student Outcomes: Suggestions for Research on Teacher Training and Professional Development. Teaching and Teacher Education, 25:12-23, 2009.

8 Jim Kuijpers, An Integrated Professional Development Model for Effective Teaching. Teaching and Teacher Education, 26: 1687-1694, 2010.
} 
melakukan pengembangan diri, yang tentunya perlu didukung oleh semua pihak yang terlibat langsung atau tidak langsung dalam dunia pendidikan, baik itu sekolah, pemerintah, dan masyarakat.

Di samping dari sisi waktu pelaksanaan, kegiatan pengembangan diri dapat dilihat pula dari sumber (agent) yang menginisiasi kegiatan dimaksud. Berdasarkan kriteria ini pengembangan profesionalisme guru dapat dibagi menjadi dua: kegiatan pengembangan diri yang bermula dari diri guru itu sendiri dan pengembangan yang diinisiasi oleh pihak di luar guru tersebut. ${ }^{9}$

Terdapat minimal lima 5 jenis pengembangan diri guru yang bersumber dari guru sendiri: memonitor kemampuan diri (self-monitoring), penulisan jurnal mengajar (teaching journal writing), saling observasi antarguru (peer observation), kelompok guru yang saling mendukung (teacher support group), dan mengajar bersama (team teaching). Pengembangan profesionalisme guru yang bersumber dari luar diri guru dimaksud dapat berupa kegiatan pengumpulan portofolio mengajar, mengikuti workshop, mengikuti seminar dan konferensi dan lain-lain. Dari kedua jenis pengembangan profesionalisme guru di atas dapat dilihat bahwa jenis pertama lebih memberikan akses kepada guru, karena untuk melaksanakannya guru hanya memerlukan keinginan dan konsistensi. Sedangkan untuk jenis kedua, guru harus menunggu kegiatan tersebut diadakan oleh pihak luar dan sering kali mereka harus meninggalkan sekolah dan mengeluarkan biaya yang cukup banyak untuk dapat berpartisipasi. Sehingga dari segi fisibilitas bentuk kegiatan yang pertama lebih potensial untuk dilaksanakan.

\section{Lesson Study dan Pengembangan Profesionalisme Guru}

Salah satu bentuk pengembangan profesionalisme yang sedang menjadi trend saat ini adalah Lesson Study (LS). LS sudah mulai berkembang di Jepang sejak tahun 1870an (70 tahun sebelum dikenalkannya penelitian tindakan kelas (PTK). LS dapat didefinisikan sebagai sebuah proses dalam usaha memperbaiki pengajaran dan pengembangan ilmu yang merupakan

9 Muhammad Amin, "What Makes Teachers of EFL Professional or Unprofessional". Universitas Negeri Malang. Disertasi tidak dipublikasikan, 2013. 
model pembelajaran yang pertama kali dikembangkan di Jepang. ${ }^{10}$ Di negara asal metode ini para guru bekerja sama dalam kelompok kecil untuk merencanakan, mengajarkan, mengobservasi, menganalisa, dan memperbaiki proses pembelajaran di kelas. Begitu populernya kegiatan ini sehingga di Jepang hampir semua guru terlibat dalam kegiatan LS. Mereka menerapkannya di sekolah mereka sendiri (dengan bekerja sama dengan guru dan pihak sekolah lainnya) atau juga bekerja sama dengan sekolah lain yang menerapkan kegiatan yang sama. Hasil kegiatan dan pelaksanaan LS ini akan dipublikasikan dan disebarkan secara nasional. Dengan demikian dapat dikatakan bahwa di Jepang kegiatan LS sudah bersifat nasional dan merupakan bagian integral kegiatan guru karena sudah diinisiasi dan dilaksanakan guru. Secara lebih rinci berikut adalah beberapa manfaat dari penerapan kegiatan LS menurut Steapnek et al: ${ }^{11}$

a. LS memungkinkan guru belajar dari kegiatan mengajar mereka seharihari karena Lesson merupakan salah satu obyek penelitian.

b. LS menyediakan sarana bagi guru untuk berkolaborasi dengan guru yang lain.

c. LS memberi kesempatan kepada guru untuk mengembangkan diri dalam usaha meningkatkan kemampuan mereka melakukan tugas sebagai pengajar dan pendidik di sekolah.

Di samping ketiga manfaat di atas tentu saja apabila kualitas proses pembelajaran sudah semakin baik maka sebagaimana hasil penelitian Hattie ${ }^{12}$ tingkat capaian pembelajaran siswa juga akan meningkat, dan tentu saja kita sepakat bahwa ini adalah salah satu tujuan utama proses pembelajaran dilakukan.

\footnotetext{
${ }^{10}$ James W Stigler et al, The teaching gap: Best ideas from the world's teachers for improving education in the classroom. New York: Summit Books, 1999.

${ }^{11}$ Jennifer Stepanek et al, Leading lesson study: A practical guide for teachers and facilitators, Thousand Oaks, CA: Corwin Press, 2007.

${ }^{12}$ John Hattie, "Teachers Make a Difference. What Is the Research Evidence?” (pp. 1-17) Australian Council for Educational Research Annual Conference on Building Teacher Quality. Auckland: University of Auckland, 2003.
} 
Manfaat pertama berhubungan dengan pengembangan karier guru sebagaimana diatur dalam Permenpan Nomor 16 tahun 2019 untuk kenaikan pangkat ke jenjang tertentu guru diwajibkan menghasilkan karya ilmiah yang dipublikasikan. Pelaksanaan kegiatan LS akan menjadi salah satu sarana bagi guru untuk memenuhi persyaratan kenaikan pangkat dimaksud karena LS ini memungkinkan kegiatan pembelajaran sehari-hari mereka dapat menjadi topik dan obyek penelitian yang yang hasilnya dapat dipublikasikan. Demikian halnya dengan manfaat yang kedua kegiatan LS memfasilitasi guru menjalin hubungan kerjasama dalam berbagi ilmu dan pengalaman mengingat kenyataan bahwa guru memiliki pengetahuan dan pengalaman yang beragam sebagai akibat dari pendidikan dan pelatihan yang mungkin berbeda, masa kerja yang berbeda, serta pengalaman mengajar yang berbeda. Kerjasama (kolaborasi) ini akan membantu mencapai manfaat yang ketiga yaitu guru memperoleh kesempatan belajar satu dengan yang lain yang dengannya mereka akan berkembang secara profesional dan mungkin juga personal.

\section{Langkah-langkah Penerapan Kegiatan Lesson Study}

Secara praktik dapat dikatakan bahwa kegiatan LS merupakan bentuk lain dari penelitian tindakan kelas (PTK). Dilihat dari waktu dikenalkannya kedua jenis penelitian ini maka boleh jadi PTK yang mengikuti prinsip penelitian LS. Kegiatan ini sebagaimana PTK terdiri dari beberapa siklus yang di masing-masing siklus terdiri dari beberapa proses kegiatan meliputi: plan, do, dan see. Meskipun dalam teori ada tiga langkah yang dilakukan, dalam praktik nya kegiatan LS menerapkan empat (4) langkah yaitu: merencanakan (planning), pengajaran (implementation), pengamatan (observation), dan refleksi (reflection). Walaupun secara esensi ada kesamaan di antara kedua jenis penelitian ini, ada perbedaan pada penggunaan istilah. Diantaranya siklus pada LS menggunakan istilah plan, do, dan see, yang pada dasarnya dapat diterjemahkan sebagai merencanakan, melaksanakan, dan mengobservasi. 
Initial Meeting of the Lesson Study Team

- Establish the ground rules

- Identify the case pupils

- Agree the learning focus for the case pupils

- Identify a teaching technique to develop or improve which addresses the learning focus

- Define a research question

\section{First Research Lesson}

- Teachers A, B, C jointly plan Research Lesson 1

- Teacher A teaches it

- Teachers B and C observe the case pupils

- Interview the case pupils

- Hold a post-lesson professional learning conversation

\section{Second Research Lesson}

- Teachers A, B, C jointly plan Research Lesson 2

- Teacher A teaches it

- Teachers B and C observe the case pupils

- Interview the case pupils

- Hold a post-lesson professional learning conversation

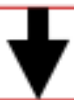

Third Research Lesson

- Teachers A, B, C jointly plan Research Lesson 3

- Teacher A teaches it

- Teachers B and C observe the case pupils

- Interview the case pupils

- Hold a post-lesson professional learning conversation

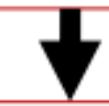

Share / Make Use of Outcomes, e.g.:

- Inform overall day-to-day teaching of the lesson study team

- $\quad$ Discuss with senior leaders

- Share informally with other teachers in school

Gambar 1. Siklus Pelaksanaan Kegiatan Lesson Study 
Secara lebih rinci proses dan siklus pelaksanaan kegiatan LS dapat dilihat pada bagan 1 di bawah ini. Dari bagan di atas dapat dilihat bahwa kegiatan LS adalah kegiatan berkesinambungan yang dimulai dengan proses mengidentifikasi masalah pembelajaran, merencanakan penyelesaian masalah yang sudah teridentifikasi, mencoba menerapkan solusi yang telah direncanakan, kemudian merefleksikan sejauh mana solusi yang diusulkan menyelesaikan masalah yang dihadapi. Dari hasil refleksi ini akan dirumuskan usulan penyelesaian masalah berikutnya, yang nantinya juga akan diterapkan, dan dievaluasi hasilnya sebagaimana pada siklus pertama. Hal ini akan terus dilakukan sehingga satu demi satu masalah pembelajaran yang dihadapi akan diselesaikan.

\section{METODE PELAKSANAAN}

\section{Lokasi Kegiatan dan Sasaran}

Kegiatan ini dilaksanakan di Pondok Pesantren Nurul Haramain Putra NW Narmada pimpinan TGH. Hasanain Juaini. Peserta penyuluhan adalah para guru pondok pesantren yang saat ini aktif mengajar di ponpes tersebut. Jumlah peserta yang mengikuti kegiatan ini adalah 31 orang guru mata pelajaran yang ada di Pondok Pesantren Nurul Haramain Narmada. Lokasi kegiatan ini dipilih karena para guru pada ponpes ini belum pernah melakukan kegiatan lesson study dan para gurunya belum mendapatkan informasi yang cukup tentang lesson study. Para guru tentu sangat membutuhkan adanya kegiatan penyuluhan yang akan memberikan mereka informasi yang dibutuhkan terkait langkah-langkah pelaksanaan lesson study yang masih cukup asing bagi mereka.

\section{Langkah-langkah Kegiatan}

\section{a. Tahap Observasi Kebutuhan Peserta}

Sebelum melakukan kegiatan penyuluhan, tim penyuluh melakukan pengumpulan informasi terkait lesson study dari para guru sekolah. Kegiatan ini dilakukan dengan menggunakan teknik kuesioner dan wawancara terkait lesson study. Dari hasil analisis kuesioner yang 
dikumpulkan diperoleh informasi bahwa para guru si sekolah tersebut belum memiliki pengetahuan yang memadai tentang kegiatan Lesson Study (LS), dan belum merasakan manfaat penyuluhan yang diikuti. Di samping itu, mereka juga tertarik untuk melaksanakan kegiatan LS tersebut. Dengan demikian, strategi yang dirasakan tepat untuk digunakan adalah penyuluhan dengan pendekatan 'take out and get in'. yang maksudnya penyuluhan diberikan didasarkan pengetahuan awal yang dimiliki para peserta.

\section{b. Tahap Pelaksanaan Penyuluhan}

Strategi yang dirasakan tepat untuk digunakan adalah penyuluhan dengan pendekatan 'take out and get in' yang didasarkan pengetahuan awal yang dimiliki para peserta. Pelaksanaan kegiatan penyuluhan ini dilakukan dalam tiga sesi: pertama sesi pemaparan materi, kedua sesi tanya-jawab, dan ketiga sesi sharing terkait manfaat dan hambatan yang dihadapi oleh peserta untuk melakukan kegiatan lesson study ini. Pada sesi pertama, dilakukan penyampaian materi tentang landasan teoritis terkait manfaat penting lesson study, perbedaan lesson study dengan PTK, dan terakhir langkah-kangkah pelaksanaan lesson study. Pada sesi kedua dilakukan tanya-jawab terkait hal-hal yang kurang jelas bagi peserta dan perlu diklarifikasi oleh pemateri. Pada sesi terakhir, dilakukan sharing terkait manfaat dan hambatan yang dirasakan oleh peserta berkaitan dengan kesiapan para guru, kesiapan pihak ponpes, dan dukungan fasilitas yang ada di ponpes.

\section{c. Tahap Evaluasi Kegiatan}

Setelah penyampaian materi presentasi, dilakukan evaluasi untuk mengetahui sejauh mana pemahaman para guru tentang materi lesson study ini. Selain itu, dilakukan pula evaluasi terkait manfaat dan hambatan yang dirasakan oleh para guru dalam melaksanakan lesson study. Dari hasil diskusi setelah presentasi dilakukan diidentifikasi beberapa masalah yang dirasakan oleh peserta untuk melaksanakan kegiatan Lesson Study ini seperti padatnya jadwal mengajar dan 
kurangnya kesadaran melakukan pengembangan profesionalisme guru. Akan tetapi melalui sinergitas guru dan dukungan manajemen sekolah serta kesediaan dukungan dari pihak kampus program LS ini sangat mungkin untuk dilaksanakan khalayak sasaran dan diharapkan nantinya akan mendapatkan manfaat dan hasil yang maksimal.

\section{PEMBAHASAN}

\section{Manfaat}

Berdasarkan hasil analisa data ditemukan bahwa semua guru tidak meragukan akan manfaat yang dapat diperoleh dari penerapan kegiatan LS ini. Mereka setuju bahwa kegiatan LS ini akan potensial bermanfaat bagi guru untuk meningkatkan kemampuan mengajar mereka dan hasilnya akan berdampak pada peningkatan capaian pembelajaran siswa, akan tetapi mereka juga melihat tantangan dan masalah yang akan muncul apabila kegiatan LS ini diterapkan di sekolah mereka, minimal untuk kondisi yang sekarang. Masalah dimaksud diuraikan pada sub-bagian tantangan berikut ini.

\section{Tantangan}

Kendala utama yang diidentifikasi guru-guru tersebut adalah kurangnya SDM yang dimiliki. Kegiatan LS yang menghendaki beberapa guru mata pelajaran yang sama hadir dan melakukan langkah-langkah pelaksanaan LS secara bersama akan sulit terjadi. Hal ini disebabkan padatnya jadwal mengajar mereka (guru harus mengajar minimal 24 jam pelajaran untuk memperoleh tunjangan sertifikasi mereka dicairkan dan banyak dari mereka yang mengajar lebih dari 30 jam pelajaran). Sehingga kalau mereka melakukan kegiatan LS, banyak kelas yang tidak bisa dihadiri guru mereka. Tantangan kedua berhubungan dengan pengetahuan dan keterampilan untuk mengadakan kegiatan LS dimaksud dan tentu saja bagaimana menuliskannya menjadi sebuah karya tulis ilmiah yang bernilai angka kredit. Para guru tersebut, meskipun telah mengikuti kegiatan penyuluhan masih merasa perlu mendapatkan pengetahuan yang lebih rinci tentang langkah-langkah 
pelaksanaan LS dan sekaligus pendampingan dalam keseluruhan proses LS di lapangan.

\section{KESIMPULAN DAN SARAN}

Setelah kegiatan pengabdian dilaksanakan, dengan merujuk kepada proses selama presentasi materi berlangsung, sesi tanya jawab, dan juga hasil analisa angket, dapat ditarik beberapa kesimpulan: (1) kegiatan LS adalah kegiatan yang belum begitu populer di antara guru-guru yang mengajar di Pondok Pesantren Haramain Putra; (2) para guru peserta penyuluhan menyadari manfaat yang dapat diperoleh dari kegiatan LS ini dan oleh karenanya berniat untuk melakukan kegiatan LS dimaksud; dan (3) para guru juga mengidentifikasi beberapa hal yang kemungkinan menjadi hambatan dalam kegiatan ini. Beberapa diantaranya adalah terbatasnya SDM dan adanya komitmen melaksanakan kegiatan dengan prinsip LS yang collaborative, collegial, continuous, dan mutual learning; (4) para guru masih masih memerlukan bimbingan dan pendampingan dalam praktik pelaksanaan kegiatan LS.

Saran dari penulis adalah semua pihak yang terlibat dalam kegiatan pendidikan di sekolah harus bersinergi untuk mendukung suksesnya pelaksanaan kegiatan LS. Pihak sekolah perlu mengagendakan kegiatan workshop atau pembimbingan oleh ahli minimal sekali untuk tahap uji coba. Kemudian menindaklanjutinya dengan merencanakan, melaksanakan, mengevaluasi, dan membuat catatan kegiatan pada jurnal, sampai ke tahap akhir yakni menyusun tulisan dan memublikasikannya pada jurnal.

Langkah besar memang selalu dimulai dari langkah awal. Hasil yang sempurna kadang dicapai melalui proses panjang dan tidak mudah. Akan tetapi, memalui proses pembiasaan, bisa dipastikan guru akan mendapatkan hasil maksimal yang diharapkan. 


\section{UCAPAN TERIMA KASIH}

Segala puji bagi Allah, Tuhan yang maha Esa, atas rahmat dan karuniaNya sehingga kegiatan pengabdian kepada masyarakat ini dapat dilaksanakan sebagaimana direncanakan. Terselenggaranya kegiatan ini tidak terlepas dari dukungan dari pihak Universitas Mataram terutama dalam hal pendanaan PNBP. Oleh karenanya tim pengabdian ini mengucapkan banyak terima kasih atas dukungan yang diberikan. Artikel ini adalah salah satu bentuk pertanggungjawaban kegiatan PPM yang telah dilaksanakan. Meskipun usaha maksimal sudah dilakukan, tim menyadari bahwa tulisan ini masih perlu adanya perbaikan. Oleh sebab itu komentar dan masukan dari para pembaca sangat diharapkan demi perbaikan pelaksanaan kegiatan dan pertanggungjawaban yang lebih baik di masa yang akan datang.

\section{DAFTAR PUSTAKA}

Amin, M. 2013. "What Makes Teachers of EFL Professional or Unprofessional". Universitas Negeri Malang. Disertasi tidak dipublikasikan.

Amin, M. dan Saukah, A. 2015. "What Makes Teacher of EFL Professional or Unprofessional. Jurnal Excellence in Higher Education, Vol. 6, pp 12-20.

Cerbin, W dan Kopp, B. 2006. "Lesson Study as a Model for Building Pedagogical Knowledge and Improving Teaching". International Journal of Teaching and Learning in Higher Education. Vol (18) 3: 250-257.

Darling-Hammond, L. 2000. Teacher Quality and Student Achievement: A review of state policy evidence. Education Policy Analysis Archives, 8 (1).

Darling-Hammond, L., LaFors, J and Snyder, J. 2001. Educating Teachers for California's Future. Teacher Education Quarterly, Vol 28 (1):9-55.

Hattie, J. 2003. "Teachers Make a Difference: What is the Research Evidence?" Paper presented at the Australian Council for Educational Research Annual Conference, Melbourne, Australia, 19-21 October 2003.

,Teachers Make a Difference. What Is the Research Evidence? (pp. 1-

17) Australian Council for Educational Research Annual Conference on Building Teacher Quality. Auckland: University of Auckland. https://cdn.auckland.ac.nz/assets/education/hattie/docs/teachers-make-adifference-ACER-(2003).

Kuijpers, J.M., Houtveen, A.A.M dan Wubbles, T. 2010. An Integrated Professional Development Model for Effective Teaching. Teaching and Teacher Education 26: 1687-1694. 
Kyriakides, L., Creemers, B. P. M. \& Antoniou, P. 2009. Teacher Behaviour and Student Outcomes: Suggestions for Research on Teacher Training and Professional Development. Teaching and Teacher Education, 25:12-23.

Nauerth, D.A. 2015. The impact of Lesson Study Professional Development on Teacher Selfefficacy and outcome expectancy. Dissertation. Kansas: Kansas State University.

Stigler, J.W., \& Hiebert, J. 1999. The teaching gap: Best ideas from the world's teachers for improving education in the classroom. New York: Summit Books.

Stepanek, J., Appel, G., Leong, M., Mangan, M. T., \& Mitchell, M. 2007. Leading lesson study: A practical guide for teachers and facilitators. Thousand Oaks, CA: Corwin Press. 